\title{
Current Status of the Chilean Native Strawberry and the Research Needs to Convert the Species into a Commercial Crop
}

\author{
Jorge B. Retamales, ${ }^{1}$ Peter D.S. Caligari, Basilio Carrasco, and Guillermo Saud \\ Facultad de Ciencias Agrarias and Centro de Investigación en Biotecnología Silvoagrícola, Universidad de Talca, \\ Casilla 747, Talca, Chile
}

Strawberries belong to the genus Fragaria, family Rosaceae. The name is derived from the Latin fragans, due to the fragrance of the fruits. The genus Fragaria is composed of a series of polyploid species consisting of nine diploids, three tetraploids, one pentaploid, one hexaploid, and four octoploids (Hancock et al., 1999). These plants are widely distributed in the world, primarily in temperate climates, although is also possible to find them in tropical zones (Hancock, 1999). The most abundant group corresponds to the diploid species, found mainly in Europe and Asia.

\section{Historical Background}

The most important commercial species of strawberry is, undoubtedly, the octoploid F. $\times$ ananassa $(2 \mathrm{n}=8 \mathrm{x}=56)$, the common or strawberry of commerce, widely cultivated and consumed all over the world. The history of $F$. $\times$ ananassa dates back to 1716 , when a spy and amateur botanist, captainAmadée François Frezier took to France plants of $F$. chiloensis collected from the coast of south-central Chile. Once in France, these plants randomly hybridized with plants of the scarlet strawberry $(F$. virginiana) native to North America, which had arrived there several centuries earlier. Among their descendants, were some hermaphrodite self-fertile plants, which justified its classification as a new species (Hancock et al., 1999; Lavín and Maureira, 2000). In this process, F. chiloensis provided important horticultural characteristics to $F$. $\times$ ananassa, such as pest and disease resistance, large fruit size, and high photosynthetic rate (Hancock et al., 1999).

\section{Geographical Distribution}

The native Chilean strawberry [F. chiloensis (L.) Duch.] is an octoploid species $(2 \mathrm{n}=8 \mathrm{x}=$ 56) that is distributed naturally on the western coasts of North America, in Hawaii, Chile and Argentina (Hancock, 1999). Based on its morphology and geographical distribution, Staudt (1962) proposed four subspecies: F. chiloensis ssp. chiloensis (South America); F. chiloensis ssp. lucida (Washington State to California); $F$. chiloensis ssp. pacifica (California to Aleutian Islands) and $F$. chiloensis ssp. sandwicens (Hawaii). In Chile, the subspecies chiloensis is found, in which two botanical forms have been distinguished: F. chiloensis ssp. chiloensis f. chiloensis and F. chiloensis ssp. chiloensisf. patagonica. The white-fruited chiloensis form is found in home plantings located in coastal areas, between latitudes $35^{\circ}$ and $39^{\circ} \mathrm{S}$. The

$\overline{{ }^{1} E-m a i l ~ j r e t a m a l} @$ utalca.cl. patagonica form produces small red fruit, and grows both in Chile and Argentina in the wild at latitudes from 35 to $45^{\circ}$.

\section{Current Status}

The Chilean native strawberry is a species that has been used for food, drink, and ceremonial rites by Chilean native people for several centuries. Ecotypes of the species can be found in diverse soil types and in variable climatic conditions (Hancock et al., 1999; Lavín et al., 2000). In the last fifty years, the native strawberry from Chile has been increasingly displaced from its growing areas by the introduction of European, and recently, Californian cultivars of the commercial strawberry $(F$. ×ananassa) (Lavín and Maureira, 2000). This fact, along with the advance of cities and the disruption of natural habitats by humans, has restricted the availability of germplasm and has put at risk the preservation of the different ecotypes. Even though $F$. $\times$ ananassa has higher yields (20 to $70 \mathrm{t} \cdot \mathrm{ha}^{-1}$ ), the organoleptic quality of the fruit is poorer than that of $F$. chiloensis, especially regarding flavor and aromas. At present, culture of $F$. chiloensis is restricted to small plantings of white-fruited accessions in areas with coastal influence (Fig. 1), such as Curepto, Curanipe and Chovellén (Latitude $35^{\circ} \mathrm{S}$ ), Purén, Puerto Saavedra, and Contulmo (Latitude $38^{\circ} \mathrm{S}$ ); as well as red fruited accessions in the Island of Chiloé (Quemchi, Butalcura, Quellón, Mocopulli; Latitude $42^{\circ} \mathrm{S}$ ). All of these are sites with low crop diversity where ecosystems are partially degraded (Lavín et al., 2000). Even though growers obtain high prices for the fruit ( $\$ 1$ to $\$ 4 / \mathrm{kg}$ ), they have low yields ( 2 to 4 $\mathrm{t} \cdot \mathrm{ha}^{-1}$ ) of fruit of nonuniform size (Lavín and Maureira, 2000). Besides the lack of genetic improvement, low yields may be due to the limited use of modern horticultural practices (irrigation, fertilization, weed control, etc.), as well as the species' strategy of generating large number of stolons to improve its competitiveness in the ecosystem. Also, growers cultivate plants to produce both fruit and new plants; thus, plant quality is very low, and this impacts negatively on plant performance and yield. The profitability and market potential of $F$. chiloensis is also affected by a very short harvest season that extends only for 3 to 4 weeks in a given site and 9 to 10 weeks in the year (mid-November to mid-January) in Chile as a whole.

The international market is increasingly demanding exotic foods grown with the use of low inputs of agrichemicals. For that, it is required to have plant material resistant to various pests and diseases, as well as to several environmental stresses (Janick, 2001). The Chilean native strawberry has been collected in the most diverse ecological conditions, and thus, it should present tolerance and resistance to various biotic and abiotic stresses; however, most research on the response of $F$. chiloensis to stress has been done by North American scientists working with clones collected on the west coast of United States. Those studies have identified genotypes of $F$. chiloensis resistant to weevils (Doss et al., 1987), two-spotted spider mite (Shanks and Barritt, 1984), Phytophtora fragariae (Stembridge and Scott, 1959), Verticillium sp. (Arulsekar, 1979; Bringhurst et al., 1968), and powdery mildew (Hondelman, 1967; Jhooty and McKeen, 1965) and tolerance to various viruses (Miller and Waldo, 1959). Among the tolerances to abiotic stresses mentioned in the literature are water and saline stress (Hancock and Bringhurst, 1979), as well as cold tolerance (Harris, 1973). Research is needed on biotic resistance and tolerance of clones collected in Chile.

\section{Research Efforts}

Since the early 1990 s, four expeditions of scientists (from Chile, United States, Japan, and Europe) have collected germplasm of F. chiloensis in different locations and sites in southern Chile (Cameron et al., 1991; Gambardella et al., 2000; Lavín et al., 1993; Mochizuki etal., 1996). In recent years, Chilean and international scientists have studied several aspects of this species, and have characterized the morphological and genetical differences among accessions.

\section{Future Research Needs}

Up to the present, there have been only isolated efforts on research and development of this ancient crop; thus, there is a need of an integrated approach for generating cultivars and adequate plant material, developing horticultural practices, establishing postharvest handling techniques, implementing market studies, and structuring a technology transfer scheme. This is necessary to transform the Chilean native strawberry into a commerciallyviable crop that can provide fruit of high and consistent quality obtained through sustainable cultural practices to local and foreign markets during an ample period in the year. Among the critical aspects for success in this endeavor are 1) availability of genetic variability in material used for breeding, to have pest and disease resistance, increased yield and harvest season, and extended postharvest life; 2) capacity to 


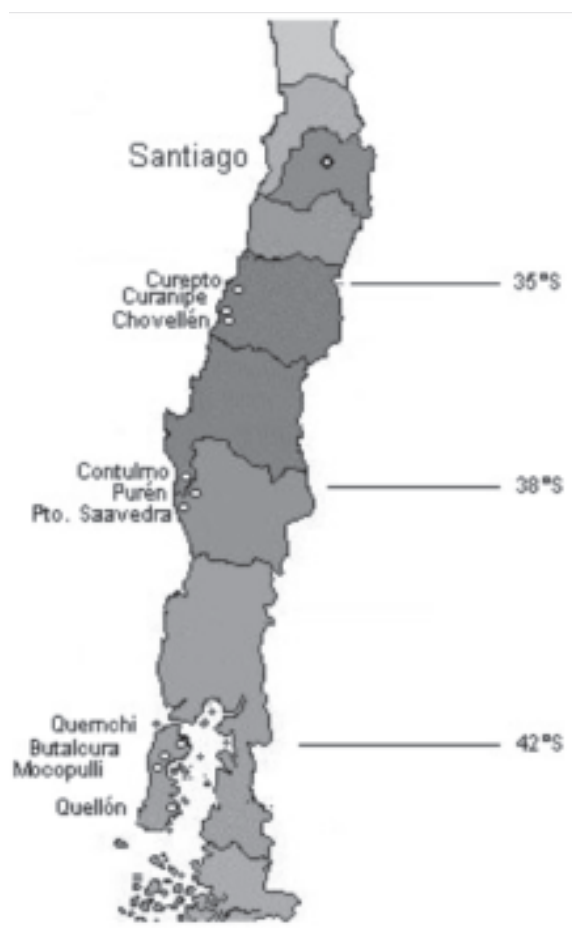

Fig. 1. Map indicating the location and latitudes of sites where $F$. chiloensis is cultivated in Chile.

produce virus-free and true-to-type plant material for the growers; 3 ) aptitude of the marketing chain to differentiate $F$. chiloensis from $F$. $\times$ ananassa; 4 ) capacity to maintain quality and price despite the production of larger volumes; and 5) ability to minimize damage and maintain adequate storage conditions of the fruit during transport on rural roads, from where the fruit is produced, and throughout the postharvest period.

\section{Conclusions}

Fragaria chiloensis is an ancient crop that has been part of the culture of native people from Chile. It is widely distributed, with clones occupying diverse ecosystems throughout this country; the species has shown resistance and tolerance to various biotic and abiotic stresses. The area cultivated with Fragaria chiloensis is being strongly reduced by the expansion of the cities, the disruption of natural habitats and the introduction of $F$. $\times$ ananassa cultivars from Europe and United States in the past century. The Chilean native strawberry has very high fruit quality (flavor, aromas); however, it has several problems that need to be solved, such as 1) fruit yields are low and fruit is nonuniform, 2) the productive season is short, 3 ) there is limited use of horticultural management practices, and 4) has an informal market and poor postharvest handling. All these problems can be solved through an integrated approach that combines basic and applied research, as well as extension activities with members of the productive chain. We are confident that in the coming years, technological and scientific developments of this species can generate the body of knowledge needed to convert the Chilean native strawberry into a crop, and thus provide the opportunity for people from other latitudes to enjoy and incorporate this fruit in their diets.

\section{Literature Cited}

Arulsekar, S. 1979. Verticillium wilt resistance in the cultivated strawberries and preliminary studies on isozymes genetics in Fragaria. Ph.D thesis. Univ. Calif., Davis.

Bringhurst, R., P. Hansche, and V. Voth. 1968. Inheritance of Verticillium wilt resistance and the correlation of resistance with performance traits of the strawberry. J. Amer. Soc. Hort. Sci. 92:369-375.

Cameron, J.S., C.H. Shanks, Jr., T.M. Sjulin, and C.E. Muñoz. 1991. Collection of Fragaria chiloensis in central and southern Chile, p. 108-110. In: A. Dale and J.J.Luby (eds.). The strawberry into the 21 st century. Timber Press, Portland, Ore.

Doss, R.P., C.H. Shanks, Jr., J.D. Chamberlain, and K.L. Garth. 1987. Role of leaf hairs in resistance of a clone of beach strawberry, Fragaria chiloensis, to feeding by adult black vine weevil, Otiorhynchus sulcatus (F.) (Coleoptera: Curculionidae). Environ. Entomol. 16:764-768.

Gambardella, M., J.M. López-Aranda, W. Faedi, P.H. Roudeillac, and R. Infante. 2000. Collection of wild and cultivated native Fragaria in southern Chile. Acta Hort. 567:61-63.

Hancock, J.F. 1999. Strawberries. CABI Publ., New York.

Hancock, J.F., A. Lavín, and J.B. Retamales. 1999. Our southern strawberry heritage: Fragaria chiloensis of Chile. HortScience 34:814-816.

Hancock, J.F. and R. Bringhurst. 1979. Ecological differentiation in perennial, octoploid species of Fragaria. Amer. J. Bot. 66:367-375.

Harris, R. 1973. Relative hardiness of strawberry cultivars at three times of the winter. Can. J. Plant. Sci. 53:147-152.

Hondelman, W. 1967. Feldbeobachtungen zum Mehltaubefall von Erdbeer-samlingen. Nachrichtenbl. Deustsch. Pflanzenschutzd. (Braunschweig) 19:137-139.

Janick, J. 2001. New crops for the 21st century, p. 307-327. In: J. Nösberger, H.H. Geiger, and P.C. Struik (eds.). Crop science: Progress and prospects. CABI Publ., New York.

Jhooty, J. and W. McKeen. 1965. Studies on powdery mildew of strawberry caused by Sphaeroteca macularis. Phytopathology 55:281-285.

Lavín, A., C. Muñoz, J.R. Ballington, and J.S. Cameron. 1993. Colección de Fragaria chiloensis L. en la X y XI regiones de Chile. Simiente (Chile) 63:18-20.

Lavín, A. and M. Maureira. 2000. La frutilla chilena de fruto blanco. Inst. Nacional de Investigaciones Agropecuarias (Chile) Boletín INIA 39.

Lavín, A., A. Del Pozo, and M. Maureira. 2000 Distribución de Fragaria chiloensis (L.) Duch. en Chile. Plant Genet. Resour. 122:24-28.

Miller, P. and G. Waldo. 1959. The virus tolerance of Fragaria chiloensis compared with the Marshall variety. Plant Dis. Rpt. 43:1120-1131.

Mochizuki, T., A. Cubillos, A. Lavín, I. Matus, A. Torres, P. León, S. Suzuki, and Y. Okawara. 1996. Expedition for collection of wild strawberries in central Chile. Natl. Res. Inst. Veg. Ornamental Plants Tea Bul. Jpn. Ser. A(11):119-130

Shanks, C. and B. Barritt. 1984. Resistance of Fragaria chiloensis clones to the two spotted spider mite. HortScience 19:640-641.

Staudt, G. 1962. Taxonomic studies in the genus Fragaria, typification of Fragaria species known at the time of Linnaeus. Can. J. Bot. 40:869-885.

Stembridge, G. and D. Scott. 1959. Inheritance of resistance of strawberry to the common race of the red stele root rot fungus. Plant Dis. Rpt. 43:1091-1094. 